\title{
ACCOUNTING ASPECTS OF THE ACQUISITION OF TANGIBLE ASSETS THROUGH LEASING
}

\author{
PhD Student Ionela Cornelia Stanciu, ,, Valahia” University of Târgovişte, \\ e-mail:sionela09@yahoo.com \\ Professor PhD Nicolae Todea, , 1 Decembrie 1918” University of Alba Iulia, e-mail: \\ ntodea@uab.ro
}

ABSTRACT: The present paper approaches problems on lease operations. A lease is an agreement whereby the lessor conveys to the lessee in return for a payment or series of payments the right to use an asset for an agreed period of time. A finance lease is a lease that transfers substantially all the risks and rewards incident to ownership of an asset. Title may or may not eventually be transferred. A lease classified as an operating lease if it does not transfer substantially all risks and rewards to ownership. Since the transaction between a lessor and a lessee is based on a lease agreement commom to both parties, it is appropriate to use consistent definitions. The application of these definitions to the differing circumstances of the two parties may sometimes result in the same lease being classified differently by lessor and lessee.

Keywords: leasing, lessor, finance lease

JEL Codes: $M$ 41, O10

\section{The concept of leasing}

The word "Leasing" comes from English, from noun "lease" and the verb "to lease" that would translate in a first sense, the "rent". Development in the last decades of this product confirmed but a particular form of financing, whose name was far from the original understanding, represented today more than verbs "to rent or to hire."

International Accounting Standard IAS 17 "Leasing" requires that leasing is an "agreement in which lessor conveys to the lessee, in exchange for a payment or a series of payments, the right to use a good an agreed period of time."

Romanian legislation on regulation of leasing operations defines the eloquent and clearsightedness with this notion of leasing. Article 1 of Government Ordinance no.51/28.08.1997, republished in the Official Gazette 9 of 12 January 2000, as amended by Law no.287/2006, specifies: "This ordinance applies to operations by leasing a part, called the lessor / financier forward to a period right to use the property, whose owner is the other party, called user, at its request, for a periodic payments, known as lease rate and at the end of the lease, lessor / funding pledges to respect the right of the user's option to purchase, to extend the leasing contract or terminate the contractual relationship. " The user can choose to purchase the property before the end of the lease, if the parties so agree and if the user pays all the obligations assumed by contract.

Classification of leasing operations as financial or operational leasing has more than fund the transaction from the contract.

financial leasing operation that is transferred to a large extent, all the risks and benefits of ownership of the property. Eventually, the title of ownership of the property can be transferred or

\footnotetext{
${ }^{1}$ IAS 17 , paragraph 3.
} 
end user.Examples of situations in which a leasing operation is classified, normally, as financial leasing are are:

a) the lease transfers ownership of asset to the lessee by the end of the lease term; b) the lessee has the option to purchase the asset at a price which is expected to be sufficiently lower than the fair value at the date the option becomes exercisable such that, at the inception of the lease, it is reasonably certain that the option will be exercised; c) the duration of the lease covers, for the most part, the economic life of the asset, even if title to property is not transferred;

d) at the beginning of the lease, the current value of the minimum lease payments is at least equal to almost the entire fair value of the property under lease, and e) the leased assets are of a specialized nature such that only the lessee can use them without major modifications being made.

Financial leasing has the particularity required residents to recognize the goods covered in assets balance, with the recognition of related debt, even if they do not have ownership over them.

In the case of financial leasing, the user (lessee) is treated in terms of financial as owner. Amortization of property covered by the contract of leasing is in financial leasing by the user and all user who deduct interest.

Lessors must register exit from asset management, asset sold claims related to the residual value and deferred income. As billing rates for leasing must be recognized as income from interest income for the period. The rate of leasing in the financial leasing contract is made up of the share of the entry of the property plus interest leasing, which is comparable to the average bank interest rates.

Operational leasing is the leasing operation that does not fall into the category of financial leasing. In the lease operational funding (lessor) is treated in terms of financial and ownership. Amortization of property under a leasing contract is made operational by the financier, with the possibility amortization entire value of the property minus the residual value during the contract, but not less than 3 years. The user is the one who deduct rent (leasing rate). The rate of leasing under operational lease is composed of the share of depreciation calculated legal plus a profit determined by negotiation. Operational leasing particularities that the property remains the property lessor and is amortized by it during the useful life, and tenants will only leasing company invoices and payment.

\section{Regulators accounting for leasing}

In the last period of time, in Romania the legal framework for accounting has made a series of changes including the scope of financial and operational lease. Mutations had influences on both parties involved in the leasing transaction.

In this regard, the first rules of accounting for leasing transactions were carried out by OMFP No. 686/1999 on the registration rules in accounting for leasing transactions. In Romania through these regulations was the first step towards implementation of the principle of the prevalence of Legal economy, by recognizing the lease at the donors that financial restraint and to the user accounts assets became tangible fixed assets for depreciation expense is tax deductible.

Subsequently, OMFP no. 686/1999 was repealed by the accounting rules simplified, harmonized with European Directives, approved by OMFP no. 306/2002, which order was applied as small and medium enterprises, and enterprises.

Large enterprises applied OMFP no. 94/2001, which also brought important improvements on the harmonization of accounting leasing operations through the application of IAS 17 "Leasing".

It considers a shortfall caused by the Order no. 94/2001 and the Order nr.306/2002 consisting of the balance that companies leasing add negative values of the stations "net assets" as a 
result of the inclusion into the position "Property, financial leasing of claims without staggering their short and long term.

The negative aspects brought about by the application nr.306/2002 Order and Order no. $94 / 2001$ were canceled by repealing them at the time of entry into force of Order $1752 / 2005$, for approval regulators accounting in accordance with UE Directives. The novelty lies in the fact that, under accounting rules developed in accordance with Directive IV of the European Economic Community in art.38 paragraph. 2 provides that "in case of entities whose main activity is leasing activity in turnover and net includes interest due these contracts related to the reporting period. Thus, noted that, from what I semester of 2006, in the balance sheet leasing companies, financial fixed assets are staggered short and long term, and in the profit and loss account is set inclusion in the turnover of net interest income leasing.

The tax with effect from 01.01.2007, supplements and amends Law no. 571/2003, bringing a series of changes in the business of financial leasing. The main changes on the definition of financial leasing contract consist of:

- "leasing period exceeds $80 \%$ of the maximum normal operation of the property subject to lease, in the interest of this definition, the lease includes any period for which the leasing contract may be extended:

- the total value of the lease rates, less spending accessories, is greater than or equal to the entry of the property. ${ }^{2 "}$

The same Code provides tax with effect from 01.01.2008, approved by O.U.G. nr.106/2007 of 14.10.2007 amending Law no. 571/2003 tax code, published in the Official Gazette, Part I, nr.703 of 18.10.2007. Order no. 1752/2005 has been amended and supplemented by Order no. 2374/2007, published in the Official Gazette of Romania no.25/14.01.2008. Thus, the point 90, after paragraph (4) to introduce a new paragraph, (5) on the leaseback transaction.

In the field of leasing operations, identified major changes during the year 2006 by Government Ordinance no. 28/2006, published in the Official Gazette of Romania no. 89/2006 on measures regulator financial services. Thus, the leasing companies have become Non-bank Financial Institutions and therefore will organize and lead the accounts according to rules adopted by the central bank spcifice.

It also provides a harmonized with the O.G no.28/2006 and the rules issued by the central bank which establishes the regime of survey and regulator the lease and leasing operations, one of the most important changes to the ordinance and the system is operational on leasing setting minimum capital to the establishment of leasing companies, capital subscribed and paid in cash equal to the equivalent in local currency - RON - the sum of 200.000 euros.

In naturally, with the assimilation of companies leasing system of banking and establish binding law in their reporting and the right to consult the credit risk information at Central banking risks. Non-bank financial institutions are required to establish the company stock. The name of an entity that can conduct business lending, will include the phrase "non-bank financial institution " or its abbreviation "IFN". The phrase " non-bank financial institution " will be used in the name header, official documents, contracts or other such documents, advertisements or advertising ${ }^{3}$.

Following the dynamic evolution of the legislative framework governing the leasing activity in Romania is seen an attempt to harmonize it with European Directives and International Standards of Accounting. In order to harmonize the legislative framework in Romania with IAS 17, that we would be necessary to carry out details of: recognition in time contract accounting for financial leasing, accounting treatment of the residual value paid in advance, the registration of interest claim on leasing, The insurance included in the leasing contract and the nature of revenue and expenditure exchange billing.

\footnotetext{
${ }^{2}$ Law no. 571/2003 on Fiscal Code, published in the Official Gazette no. 927/2003, Article 7, Section 7 and 8.

${ }^{3}$ Law no. 28/26.01.2006 on some measures, financial, tax, Article 6, paragraph 1.
} 


\section{Parallel between leasing and credit}

Leasing, financing transaction that undoubtedly derived from classical transaction credit and born of the need for expansion of the latter, with the main purpose of guidance to support investment complements the scope and innovation of trade with money practiced since ancient times.

What unites the operations is determined to promote the general concept of investing with confidence and risk management related.

Although leasing operations have recently emerged as a distinct operations in Romania, but they are proving increasingly more to be a viable alternative for financing assets of any kind. Moreover, each of the two forms have advantages and disadvantages of both natural conception and operational. In practice it is found that the user Romanian funds, requesting that the funding does not appear to be informed but rather to vote in the full knowledge between the two forms, so choosing mostly for the operation better known, and credit Banking.

The main difference between the two forms of financing is without doubt the right of ownership of assets financed.

In the case of the operation leasing, asset ownership remains a leasing company, the user receives only the right to use the assets in question, against a periodic payments, called the leasing rate. At the end of the lease, the user can choose to purchase the property, extend or terminate the contract contractual relationships, but the user becomes owner of assets only after expression purchasing option, pay the residual value and obviously after compliance with all contractual obligations assumed.

In the employment situation of a bank loan for the purchase of any type of asset, the user becomes the owner of the property the first time, having the right to dispose of it at any time of the contract, in compliance with the obligations undertaken towards the banking institution.

Another distinction lies in highlighting the basis for calculating both the amount financed and the amount of input, the calculation is executed on the basis of financing, and the value of entry, the purchase price will include all the costs of additional assets, the so-called total price or price-DDP Delivered Duty Paid - including value added tax, any excise duty, transport costs and insurance to destination, etc.. In the case of lease, the purchase price will include transportation and insurance paid to destination CIP - Carriage and Insurance Paid to - or the price paid, which includes transportation to destination CPT - Carriage Paid To - not including any additional cost or charges other than price from the supplier.

Accordingly, interest, fees and other charges are different in value. The difference is time, ultimately, the conditions of the financing and facilitation, criteria which are another different between the two forms of credit. If the bank loan, usually requested additional guarantees or collateral, if lease is assumed that the property itself warranty, and in these circumstances the procedures for obtaining financing are simpler and more accessible to a much broader category of customers.

On the other hand, according to Romanian legislation for leasing, early closure of the contract is not valid for a year before, this was due exclusively to the nature of the contract, while if the assets are purchased through credit, the owner may call option at any time closing early. Early repayment of the amount borrowed is allowed in both cases against the costs of default.

Romanian legislation in force establishes a series of advantages in terms of the acquisition of assets in the lease, tried is in this way is an impetus to investment. One of them is determined by the feature introduced in the case of procurement of goods liable to be charged in terms of customs duty, it is calculated at the end of the lease at the residual value, and not the full value of the goods, as in the case of a procurement normal.

On the other hand, taking an active case of manufactured outside the European Union, Romanian legislation stipulates that customs duties amounting to $30 \%$ of the initial asset will be 
paid to the residual value, which can not be less than $20 \%$ of the entry. Thus, the customs debt will be paid at the end of the lease and will calculate the residual value. In the case of a credit contract for the purchase of assets outside the UE, the consumer will pay customs duty - customs duties and customs fee - calculated at baseline full.

The following analysis will develop hypothetical examples reflected in tables 1 and 2, two example calculations of specific lease, and bank credit for the assets of the same type, manufactured in a member country of the European Union and the other is an extra.

Thus, regardless of the situation and hypothetical conditions such as the type of asset financed type, the purchase price, advance, and the rate of funding, we find that leasing is a final cost lower than bank credit. Differences in cost between the two financial products increased considerably when leasing used to the maximum tax benefits created by legislation in force in Romania. Thus, in Table 2 is a difference of 3763,81 euros to pay more in case of bank credit. That is actually an increase in the credit contract with $27,51 \%$ compared to the leasing contract.

Certainly that existing differences in values may materialize in direct or indirect costs higher or lower, the applicant for funding, based on entries and exits moments cash determining the composition of tax feature of this type of financing in part by direct damage to both moneys level flows and economic situation. Tax advantages granted the lease's financial definite advantage over other financial products, which in principle can be interpreted as a particular feature the industry.

Table no. 1

The composition of contracts for financing and leasing credit for manufacturing assets in the UE

\begin{tabular}{|l|c|c|l|l|l|l|l|l|l|l|c|}
\hline $\begin{array}{l}\text { Variant } \\
\text { financing }\end{array}$ & $\begin{array}{l}\text { Price } \\
\text { acquisition }\end{array}$ & $\begin{array}{l}\text { Value } \\
\text { residual }\end{array}$ & $\begin{array}{l}\text { Free } \\
\text { customs } \\
\text { Paid at } \\
\text { the } \\
\text { value } \\
\text { residual }\end{array}$ & $\begin{array}{l}\text { Free } \\
\text { Customs } \\
\text { paid } \\
\text { advance }\end{array}$ & $\begin{array}{l}\text { TVA } \\
\text { Paid in } \\
\text { advace }\end{array}$ & $\begin{array}{l}\text { Period } \\
\text { months }\end{array}$ & Advance & $\begin{array}{l}\text { Amount } \\
\text { funded }\end{array}$ & $\begin{array}{l}\text { Rate } \\
\text { interest }\end{array}$ & $\begin{array}{l}\text { Rate } \\
\text { average } \\
\text { monthly }\end{array}$ & $\begin{array}{l}\text { Rate } \\
\text { average } \\
\text { monthly }\end{array}$ \\
\hline Leasing & 10.000 & 2.000 & 0 & NO & NO & 36 & 2.000 & 8.000 & $9 \%$ & 297,23 & $13.080,19$ \\
\hline Credit & 10.000 & NO & NO & 0 & 1.900 & 36 & 2.000 & 9.900 & $9 \%$ & 315 & 13.340 \\
\hline $\begin{array}{l}\text { The } \\
\text { difference }\end{array}$ & & & & & & & & & & & 259,81 \\
\hline
\end{tabular}

Table no. 2

The composition of contracts for leasing and financing credit assets manufactured outside UE

\begin{tabular}{|l|l|l|l|l|l|l|l|l|l|l|l|}
\hline $\begin{array}{l}\text { Variant } \\
\text { financing }\end{array}$ & $\begin{array}{l}\text { Price } \\
\text { acquisition }\end{array}$ & $\begin{array}{l}\text { Value } \\
\text { residual }\end{array}$ & $\begin{array}{l}\text { Free } \\
\text { customs } \\
\text { Paid at } \\
\text { the } \\
\text { value } \\
\text { residual }\end{array}$ & $\begin{array}{l}\text { Free } \\
\text { Customs } \\
\text { paid } \\
\text { advance }\end{array}$ & $\begin{array}{l}\text { TVA } \\
\text { Paid in } \\
\text { advace }\end{array}$ & $\begin{array}{l}\text { Period } \\
\text { months }\end{array}$ & Advance & $\begin{array}{l}\text { Amount } \\
\text { funded }\end{array}$ & $\begin{array}{l}\text { Rate } \\
\text { interest }\end{array}$ & $\begin{array}{l}\text { Rate } \\
\text { average } \\
\text { monthly }\end{array}$ & $\begin{array}{l}\text { Rate } \\
\text { average } \\
\text { monthly }\end{array}$ \\
\hline Leasing & 10.000 & 2.000 & 600 & NO & NO & 36 & 2.000 & 8.000 & $9 \%$ & 297,23 & $13.680,19$ \\
\hline Credit & 10.000 & NO & NO & 3.000 & 2.470 & 36 & 2.000 & 13,470 & $9 \%$ & 429 & 17.440 \\
\hline $\begin{array}{l}\text { The } \\
\text { difference }\end{array}$ & & & & & & & & & & & \\
\hline
\end{tabular}




\section{Comparison between the purchase of tangible assets by financial leasing and credit}

S.C. X SRL take the financial leasing a car VOLKSWAGEN Caddy KOMBI 1.9/75 from the company leasing Y IFN SA Car purchase is made at the entrance without TVA 14226,91 euro and $19 \%$ TVA.

The leasing contract is concluded between S.C. X SRL and S.C. Y IFN S.A. for a period of 3 years, as an advance of 5\% and a residual value of the car of 99,59 euros. Interest on the operation of the system of granting financial leasing a car is 7,30\% per annum and is considered a linear rate applied on the amount financed the car. The normal duration of use is considered a vehicle for 6 years. In these circumstances the monthly total, plus interest rate would be 417,70 euros.

S.C. X SRL could opt for contracting a bank loan from a bank for the purchase of company cars. Where would be chosen for this variation in terms of interest of $7 \%$ per year would have to pay a monthly interest rate and the total amount of 512,99 euros against 417,70 euros as paid if the leasing contract, which is $22,81 \%$ more. This perception is due to the banks of a commission analysis of $0,5 \%$ of the loan and a management fee of $1 \%$ applicable to the loan. The commission analysis and plays a role anniversary commission which is charged by the banks at end of a year to grant credit to the amount remaining to be financed.

\section{Conclusions}

During the years 2006 - 2007, financial leasing has continued to represent the main way of development of the leasing contracts, reaching a rate of $98 \%$ of total assets financed, the remaining $2 \%$ being represented by the leasing program. In the total market lease external (cross border) entered a downward trend from year to year, he registering a total of less than $1 \%$.

Leasing market in Romania had a sustained development in recent years, but consider that the size of the market can register values much higher if some negative factors and not producing effects. Of these mention:

-the legal framework still insufficiently structured;

- manifestation of a lack of information to potential customers about leasing operations;

- factors relating to study the current Romanian economy: inflation, already low level of foreign investment, reduced efficiency of economic agents, reduced purchasing power; - due to political influences.

Given that the next time it will produce a series of mutations in mature markets such as financial, organization, regulation and supervision of leasing market, low interest rates, promote financing for terms of increasingly long and the package of laws securitization of mortgage securities is holds that will be recorded significant increases in the market equipment leasing and real estate against the backdrop of an increase in overall market lease.

Meanwhile, it considers that the Romanian leasing market is coming from increasingly reaching mature level market and that recorded positive developments in terms of:

- increasing periods of grant funding in leasing targeted mainly to finance equipment and buildings;

- a decrease in margins charged by the companies leasing the fund cheap product; - reduction in advances to the user's input to the transaction.

Also, we appreciate that Romania and through the leasing market is embedded in the general trend of concentration of capital and the phenomenon of regionalization and globalization.

Thus, leasing can be considered as an "engine of development" on economic and social in the way that mobilized on the one hand, additional sources, on the other hand, provides financing for both production and consumption and investment, not least, create new jobs.

Finally, I would like to note that the work developed is a step intended to highlight a number of topical issues and perspective on the leasing market in Romania, without the pretense of an 
exhaustive treatment, and also hoping that the issues discussed and findings raised will be a starting point for future studies.

\section{References}

1. Cenar I., Todea N., Deaconu S. C. - Contabilitate practică, Risoprint Publishing House, Cluj Napoca, 2003.

2. Constantinescu C. C. - Leasingul financiar - realitate şi perspectivă, Economic Publishing House, Bucureşti, 2006.

3. Pântea I. P., Badea Ghe. - Contabilitatea financiară românească conformă cu Directivele Europene, Intelcredo Publishing House, Deva, 2006.

4. Guide to understanding and application of International Accounting Standards IAS 17 "Leasing", CECCAR Publishing House, Bucureşti, 2004.

5. Order no.1752/2005 accounting rules for approval in accordance with European Directives, published in the Official Gazette of Romania, Part I no. 1080 of 30.11.2005.

6. Order no. 2374/2007 amending and supplementing the Ministry of Public Finance Order no. $1752 / 2005$ for approval in accordance with accounting rules Directvele European Union, published in the Official Gazette of Romania, Part I, no.25 of 14.01.2008.

7. Law no.28/28.01.2006 on certain financial measures - tax (IFN law), published in the Official Gazette of Romania, Part I no.89/31.01.2006. 